\title{
The response of runoff components and glacier mass balance to climate change for a glaciated high-mountainous catchment in the Tianshan
}

\author{
Mountains \\ Xiaoyan Wang ${ }^{\mathrm{a}, \mathrm{b}, \mathrm{c}}$, Tao Yang ${ }^{\mathrm{b} 1^{*}}$, Chong-Yu Xu ${ }^{\mathrm{b}, \mathrm{d}}$, Lihua Xiong ${ }^{\mathrm{a}}$,Pengfei Shi ${ }^{\mathrm{b}}$, Zhenya Li $^{\mathrm{b}, \mathrm{c}}$ \\ a State Key Laboratory of Water Resources and Hydropower Engineering Science, Wuhan \\ University, Wuhan 430072, China \\ b State Key Laboratory of Hydrology-Water Resources and Hydraulic Engineering, Center \\ for Global Change and Water Cycle, Hohai University, Nanjing 210098, China; \\ c School of Earth Sciences and Engineering, Hohai University, Nanjing 210098, China; \\ d Department of Geosciences, University of Oslo, P.O. Box 1047, Blindern, 0316 Oslo, Norway \\ ${ }^{1 *}$ Corresponding author: \\ Tao Yang \\ State Key Laboratory of Hydrology-Water Resources and Hydraulic Engineering \\ Hohai University, Nanjing 210098 \\ The People's Republic of China \\ Tel: (+86) 2583786017 \\ E-mail: tao.yang@hhu.edu.cn
}


Abstract: Glaciers are important freshwater storage systems in the Tianshan Mountains. Under the context of climate change, quantifying changes in glacier mass balance, the melt-season (June-September) runoff and its key runoff component (glacier runoff) is of importance for understanding the discharge composition and ensuring adequate management of water resources. In this study, the modified HBV-D (Hydrologiska Byrans Vattenbalansavdelning-D) hydrological model was used to simulate hydrological processes for a data-sparse glacierized watershed, the headwater catchment of Manas River basin (MRB) in the Tianshan Mountains. Meanwhile, the roles of three modified elements of HBV-D in simulating glacier dynamics are identified. Sequently the glacier mass balance and runoff during 1984-2006 are reconstructed and their responses to climate change are investigated. The analysis showed (1) the snow/glacier melt method makes more contribution to improving the performance of HBV-D model in simulating historical change of glacier volume, followed by the glacier dynamic method.(2) The reconstructed mass balance follows a decreased trend in the MRB. The maximum accumulation of glacier mass balance occurs in June. Snowmelt over the surface of glacier and glacier melt reach peak in June and August, respectively. Furthermore, sensitivity experiments showed increased mass balance induced by a $10 \%$ increase in precipitation cannot compensate for the decreased mass balance due to a $1{ }^{\circ} \mathrm{C}$ temperature rise. (3)Significant contribution (about 41.5\%) of runoff in glacierized area to the melt-season total runoff of the catchment is identified. Both the glacier runoff and its contribution to melt-season total runoff show increased trends during the simulation period. Compared with the melt-season mean temperature and annual precipitation over glaciers, the melt-season positive accumulated temperature over glaciers played the most important role in influencing changes in glacier runoff in MRB.The findings in this study are beneficial for implementing adaptive countermeasures for water resources management in the data-scarce glaciated high-mountainous region.

Key words: the modified HBV-D model; glacier mass balance; runoff components; climate change; the Tianshan Mountains 


\section{Introduction}

As the headwater catchment of many rivers in Central Asia, the Tianshan Mountains (TSM) is recognized as the "water tower of Central Asia". Nearly 50 million people from Kyrgyzstan, Kazakhstan, and the Xinjiang Province of China are reliant on water resources derived from the glacierized watersheds located in the Tianshan Mountains (Pritchard, 2017; Xu et al, 2018; Shi et al, 2017), which also support the downstream lowland agriculture and industry. The number of glaciers in the Tianshan Mountains reaches 15953 in the 1970s, which covers an area about $15416 \mathrm{~km}^{2}$ (Aizen et al., 2007a). The glaciers termed as a solid reservoir play an important role in the hydrological processes in the regions (Aizen et al., 1997). However, the signature of climate warming in the Tianshan Mountains is obvious over the past half-century, when the warming rate is up to $0.34{ }^{\circ} \mathrm{C} / 10 \mathrm{a}$ (Jiang et al, 2013). Furthermore, the warming has significantly affected glacier/snowmelt characteristics. A number of studies based on remote sensing observations (Aizen et al., 2007b; Kumar et al., 2019) and mass balance records in gauges (Sorg et al., 2012) have indicated a general negative glacier mass balance and decrease in ice volume in the Tianshan Mountains. It is unquestionable that change in climate, glacier area and volume would influence the local water cycle in the glacierized watersheds in mountainous regions (Hagg et al., 2007; Yang et al., 2017; Ren et al., 2018; Cui et al., 2018), further inducing the problem of water security in the lower reaches. Therefore, it is necessary to investigate changes in runoff and glacier fluctuations in these rivers for formulating applicable strategy for the management of water resources as the impact of the global warming process continues.

Reasonably calculating glacier melt processes is the basis for successfully modeling of glacier/snow-derived runoff. Both energy-balance models and temperature-index method are widely used to simulate glacier/snow melt in high-elevation mountain areas (Hock, 2005; Jiang et al., 2010; Zhang et al., 2012; Li et al., 2018). The former is based on solid physical mechanisms and has high data requirements; it therefore can only be applied in limited regions with substantial observations. In contrast, the latter has been widely applied in a number of studies due to its limited data requirements and robust performance. Thus, the 
temperature-index method has been frequently incorporated into the hydrological models to calculate runoff in glacierized catchments (Hock, 2005; Huss et al., 2008b; Immerzeel et al., 2012; Wang et al., 2018) and displayed high agreement between the simulated runoff and observation in some glacierized catchments ( Hagg et al., 2007; Gao et al., 2012). Furthermore, the enhanced-temperature-index method including the effect of potential direct solar radiation and air temperature can provide a better representation of the spatial and temporal variability of melt ( Hock, 1999; Pellicciotti et al., 2005), in contrast to the degree-day method requiring only air temperature as input. Besides, these methods have been previously used to evaluate the glacier mass balance (i.e. Braithwaite and Zhang, 1999; Kumar et al., 2016). Recently, Shi et al (2016) have reconstructed the mass balance of Xiao Dongkemadi Glacier in the central Tibetan Plateau using enhanced temperature-index method and they have found the reconstructed mass balance are in a high agreement with observation.

A number of studies have devoted to hydrological system dynamics in the Tianshan Mountains (i.e. Sun et al., 2016; Shen et al., 2018). Xu et al (2018) evaluated the changes in glacier mass balance of several headwater catchments in the Tianshan Mountains by statistical methods. Some studies have been conducted for the Manas River basin (MRB) as a representative watershed on the northern Tianshan Mountains. Luo et al (2013) developed an enhanced SWAT (Soil and Water Assessment Tool) model to simulate the daily streamflow as well as change in glacier area and explore the relationship between changes in glacier melt and meteorological factors in the MRB. In addition, the dynamics for annual runoff and snow cover in the same region have also been investigated (Lin et al., 2011; Jiang et al., 2015 ). Recently, Wang et al (2019) modified the HBV-D (Hydrologiska Byrans Vattenbalansavdelning-D) model to simulate the hydrological processes in MRB during historical period. They found that snow/glacier melt method made more contribution to improve the fitness of HBV-D model in modeling daily runoff, than the glacier dynamic method and the spatial discretization. However, we still do not know the effect of three modified elements of HBV-D (i.e. snow/glacier melt method, the spatial discretization and glacier dynamic method) for the improved simulation of the glacier volume change in MRB. 
In particular, there still is a knowledge gap about how glacier mass balance, melt-season runoff as well as its key component-glacier runoff changed in response to climate change during the recent decades in MRB. The glacier runoff in this study refers to the runoff from the glacierised area. It consists of rainfall runoff, snowmelt runoff and icemelt runoff from the glacierised area. As a continuous and in-depth research of Wang et al (2019), this article aims to: (1) reconstruct the time series of the glacier mass balance and runoff based on the modified HBV-D hydrological model during historical period (1984-2006) in the MRB; (2) investigate the variation characteristics of the simulated glacier mass balance and runoff; and (3) identify the relationship between climate change and variations in glacier mass balance, melt-season runoff as well as glacier runoff.

\section{Study Area}

The Manas River is located in the southern Junggar Basin, Xinjiang Uygur Autonomous Region (Xinjiang for short) and originates in the northern slope of the Tianshan Mountains. It is termed as the fourth biggest irrigation district in China (Zhang et al., 2014), playing an important role in the agricultural economy in Tianshan Mountains. Meanwhile, it is the largest artificial oasis area in Xinjiang. The headwater catchment of the Manas River Basin (MRB) was selected as the study area in this work. The MRB refers specifically to the catchment bounded by $84^{\circ} 30^{\prime} \sim 86^{\circ} 30^{\prime} \mathrm{E}$ longitude and $43^{\circ} \sim 44^{\circ} \mathrm{N}$ latitude, with a contributing area of 5156 $\mathrm{km}^{2}$ upstream of Kensiwate station (Figure 1). Precipitation occurs as snowfall in winter and its peak usually appears in summer months (Aizen et al., 2007a). According to Ji and Chen (2012), annual average precipitation in MRB is about $550 \mathrm{~mm}$. The monthly average temperature is under $0{ }^{\circ} \mathrm{C}$ in most months, with the exception of the period from May to September (Wang et al, 2019). Glaciers in MRB mainly occurred in elevation above $3000 \mathrm{~m}$ a.m.s.1, which covers $13 \%$ of the basin area. A near-normal distribution curve is exhibited for a plot of altitude versus glacier area for the MRB (Figure 2). Accelerated glacier retreat in the MRB has emerged in recent decades (Fan et al., 2015; Narama et al., 2010). A 17\% reduction in glacier area was observed based on remote sensing data during the year 1964-1998, with the 
annual reduction rates reaching $0.52 \%$. Moreover, a higher annual reduction rate $(0.89 \%)$ was reported for the glacier area in the MRB during the year 1998-2009 (Fan et al., 2015).

\section{Material and Methods}

\subsection{Model input data for the modified HBV-D hydrological model}

The model input includes daily precipitation, air temperature and potential solar radiation. Available observations at 6 meteorological stations (Figure 1), including daily precipitation, daily mean, minimum and maximum temperature (1981-2006), were collected from the National Climate Center. Daily potential solar radiation is calculated using the method from $\mathrm{Li}$ et al (2002). The precipitation and temperature data, reconstructed on the basis of meteorological and satellite observations, are from Wang et al (2019). They estimated the ability of constructed precipitation and temperature data to capture trend and magnitudes of observation and found the reconstructed meteorological data can be used for computation of hydrological processes in MRB. A general description about how to obtain daily precipitation and air temperature is shown below.

Daily precipitation in the base station and the lapse rate derived from corrected-TRMM precipitation data are employed to constitute the precipitation data for the MRB simulation. On account of no meteorological station existing in the MRB, the nearby Wulumuqi station is selected as the base station for the precipitation interpretation in this study. Monthly precipitation lapse rates at different elevations are generated on the basis of corrected-TRMM precipitation data from $\mathrm{Ji}$ and Chen (2012), who established regression models to link observed precipitation in meteorological stations with TRMM precipitation, geographic location (longitude and latitude) and topographic variables and demonstrated that the corrected-TRMM precipitation data have the ability to capture the spatial variability in precipitation for the MRB.

Combined Inverse Distance Weighted (IDW) and temperature lapse rate (TLR) method is employed to generate daily air temperature. All six weather stations shown in figure 1 are used in the construction of temperature data. The lapse rates of temperature in different months 
used in this study are collected from Ji (2013). He generated these lapse rates based on the observed temperature data in the meteorological stations around the MRB. The simulated daily mean temperature $\left({ }^{\circ} \mathrm{C}\right)$ on the ith day $T_{d a y, i}$ at a given interpolation station is decomposed into two components (equation 1). Please refer to Wang et al (2019) for the detailed illustration for how to simulate the above two components.

$T_{d a y, i}=T_{m o n t h, j}+\Delta T$

Other data the modified HBV-D model requires include soil type, DEM, land cover, glacier inventory and observed daily streamflow data (1981-1993) at the Kensiwate station. The available streamflow time series have gaps in the year of 1991 due to missing data. Soil texture data are obtained from Harmonized World Soil Database (HWSD). DEM data and Land cover information are taken from version 4 of SRTM data (the Shuttle Radar Topography Mission; Jarvis et al, 2008) and Chinese Resources and Environment Database, respectively. Glacier inventory data set and the daily streamflow data are collected from the Randolph Glacier Inventory 3.2 (http://www.glims.org/RGI/randolph32.html; RGI Consortium, 2013) and the Hydrological Bureau of Manas River, respectively.

\subsection{Model description}

The distributed hydrological model HBV-D (Krysanova et al., 1999) has been used in a number of studies to simulate precipitation-runoff processes, snow hydrology and glacier-hydrology (Menzel et al, 2002; Menzel et al, 2006; Liu et al, 2013). The basic simulation unit for HBV-D model is the hydrological response unit (HRU), where both meteorological elements and hydrological characteristics are supposed to be homogeneous. The key modules for HBV-D model include: snow/glacier melt, evaporation, the simulation of soil moisture and water yield, and river routing. Please refer to Krysanova et al (1999) for the detailed illustration for this model. For the sake of application in the alpine glacierized catchments, Wang et al (2019) modified the spatial discretization method in HBV-D model and added extensions to account for glacier dynamic and the effect of radiation on melt. The distinctions between the HBV-D and the modified one mainly include three parts: (1) the 
spatial discretization is realized based on elevation bands in the HBV-D model. While an alternative discretization on the basis of the elevation bands, aspect and landcover is utilized in the revised HBV-D model; (2) enhanced temperature-index model (TIM) instead of the degree-day method employed in the HBV-D model is coupled into the modified HBV-D model; (3) In the glacier module of revised HBV-D model, glacier-melt would not occur until the snow storage on the glacier surface is zero. Moreover, glacier area change is simulated be means of the volume-area scaling relation ( Liu et al., 2003), which was ignored in the HBV-D model.

As an elementary basis for this study, calibration and validation of the modified HBV-D model in the MRB have been conducted by Wang et al (2019). They concluded that the

modified version showed more satisfactory performance in reproducing daily streamflow processes and the glacier dynamic variation during the historical period, when compared with the HBV-D model. The details described in Wang et al. (2019) are not illustrated in this study. Generally the revised HBV-D model from Wang et al (2019) is applicable to achieve the goal highlighted in the introduction section of this study.

\subsection{Estimation of Mass Balance}

The reconstruction of glacier mass balance in the data-scare high-mountainous catchment is a prerequisite for enhancing our understanding of the glacier response to climate change. Modelling approach serves as a common tool for reconstructing glacier mass balance. The prevalent approaches suited for the data-scare high-mountainous catchments include degree-day method and enhanced temperature-index model (e.g. Huss et al., 2008a; Pellicciotti et al., 2005; Hock, 2003). In this study, the enhanced temperature-index method has been coupled into the modified HBV-D model and employed to reconstruct the glacier mass balance in the MRB. Meanwhile, we ignore evaporation and sublimation in the ablation calculation for glaciers, owing to their small contributions to the total glaciers mass balance (Hock, 2003; Radić and Hock, 2006).

The glacier mass balance (MB, mm w.e.) in a hydrological year (October of this 
year-September of following year) is estimated by the equation 2:

$M B=A_{c}-A_{b}$

Where $A_{c}$ is solid precipitation over the glaciers of the catchment $(\mathrm{mm}) . A_{b}$ is summation of snow melt and glaciermelt from glacier-covered part of the catchment $(\mathrm{mm})$, which is obtained from the simulations of the modified HBV-D model.

\section{Results}

\subsection{The contribution of three modified modules to the improved simulation of the glacier volume change}

In this section, the simulated glacier volume changes from 4 models (HBV-D model and three revised versions) and satellite observations (from Chinese glacier inventory data) during historical period are compared to identify the contribution of individual modified element to the improved simulation for glacier volume change. Three revised versions shown in Table 1 have been detailed in Wang et al (2019). According to Xing et al (2007), the change in satellite-observed glacier volume is about $0.29 \mathrm{~km}^{3} \mathrm{yr}^{-1}$ during 1964-2009. The simulations from HBV-D, HBV-D1,HBV-D2 and HBV-D3 are 0.41, 0.40, 0.35 and $0.31 \mathrm{~km}^{3}$ $\mathrm{yr}^{-1}$ respectively in our study. Obviously, a significant improvement of $17 \%$ in PBIAS between the simulated values from HBV-D2 and HBV-D1 is found, followed by $14 \%$ reduction between the simulated values from HBV-D3 and HBV-D2, while the improvement induced by the modification of the spatial discretization method is small through the comparison between simulated values from HBV-D and HBV-D1. These results suggested that snow/glacier melt method made more contribution to the improved simulation of the glacier volume change during historical period, followed by the glacier dynamic method.

\subsection{The response of glacier mass balance to climate change}

\subsubsection{Variations in glacier mass balance}

The time series of simulated annual basin-wide glacier mass balance is exhibited in Figure. 3a. The results reveal a large year-to-year variability with values between $-0.14 \mathrm{~m}$ w.e. and $-0.79 \mathrm{~m}$ w.e. According to the previous study, the largest glacier mass balance loss in 
nearby Urumqi No.1 Glacier occurred in the water years of 1996. This is in accordance with our result that the largest mass loss during 1984-2006 appears in the year of 1996 for the MRB. In addition, a decreased trend in the mass balance for the MRB is detected during the evaluation period (significant at the $99 \%$ level), as highlighted by many scientific reports (Liu and Liu, 2016; Xu et al., 2018) for the mass balance variations of Tianshan glaciers. Compared with the change rate in glacier mass from other studies, the loss rate in glacier mass for the MRB (-0.50 m w.e. $\mathrm{yr}^{-1}$ during the period 1984-2006) is slightly larger than Urumqi No.1 Glacier in Tianshan Mountains (-0.43 m w.e. $\mathrm{yr}^{-1}$ during the period 1985-2002; Han et al., 2006; Liu and Liu, 2016), and lower than the Altai Mountains in the Northern part of Asia (-0.69 $\mathrm{m}$ w.e. $\mathrm{yr}^{-1}$ during the period 1990-2011; Zhang et al., 2017).

Figure $3 \mathrm{~b}$ shows seasonal variations for the components of glacier mass balance. It is found the maximum accumulation (solid precipitation) occurs in May and June. Less accumulation is detected during the autumn and winter months. Snowmelt over the surface of glacier is significant between May and August and is maximal in June. In comparison with the snowmelt, glacier melt is shifted about 2 months and reaches peak in August. A large interannual variability is generally exhibited for glacier mass balance components, in particular for the glaciermelt. The examples of glacier melt in extreme years (1996 and 1991) are also shown in Figure 3b. Glaciermelt in July 1996 was two times higher than that in 1991. The ratio of glaciermelt in two mentioned extreme years is even above three in August. This is related to the effect of "snow-cover". In cold and snow-rich years glacier melt is very limited, because the entire glacier surface is covered by snow throughout most of the summer months. While in hot and snow-scarce years, the glacier surface could be completely exposed in July and August, resulting in a large amount of glaciermelt.

\subsubsection{The dependence of mass balance on precipitation and temperature}

The glaciers distributed in the MRB belong to continental glaciers; and both air temperature and precipitation are important factors influencing continental glaciers dynamic. To show the link between the glacier dynamics and temperature as well as precipitation in the MRB, the simulated annual glacier mass balance in the study area was plotted against the 
basin-wide annual precipitation and melt-season (June to September) positive accumulated temperature (PAT) over glaciers (Figure 4). A linear regression analysis suggested that glacier mass balance is weakly correlated with precipitation (statistically not significant), with a correlation coefficient only 0.13 . Whereas a closed link between PAT over glaciers and the glacier mass balance is detected, as reflected by a correlation coefficient reaching up to -0.88 (significant at the $99 \%$ level). Generally, the variation of glacier mass balance in the MRB is dominated by the melt-season air temperature. This is similar with the results of Glacier No. 1 located in the source region of the Urumqi River and other glaciers in the Chinese Tianshan (Han et al., 2006; Liu and Liu, 2016). However, the result in this paper is different from those for the maritime glaciers. For instance, the changes in annual mass balance for maritime glacier in northwest of North America are largely resulted from anomalies in winter precipitation and weakly correlated with anomalies in summer air temperature (Bitz and Battisti, 1999).

\subsubsection{The sensitivity of mass balance to climate change}

In this section, sensitivity experiments are carried out to explore the sensitivity of glacier mass balance in the MRB to climate change. The indices $\Delta B / \Delta T$ and $\Delta B / \Delta P$ are used to quantify the sensitivities of simulated glacier mass balance to a $1{ }^{\circ} \mathrm{C}$ increase of air temperature and a $10 \%$ increment in precipitation, respectively. Here $\Delta B$ denotes changes in glacier mass balance relative to mean values for the reference period 1984-2006. The results show $\Delta B / \Delta T$ and $\Delta B / \Delta P$ are about $-0.41 \mathrm{~m}$ w.e. $\mathrm{yr}^{-1}{ }^{\circ} \mathrm{C}^{-1}$ and $+0.04 \mathrm{~m}$ w.e. $\mathrm{yr}^{-1}(10 \%)^{-1}$ respectively for the MRB. Comparing with previous sensitivity experimental studies, the average $\Delta B / \Delta T$ in our study is in accordance with the estimated value $-0.42 \mathrm{~m}$ w.e.yr ${ }^{-1}{ }^{\circ} \mathrm{C}^{-1}$ (Radić and Hock, 2011) in the Tianshan Mountains and a global sensitivity estimation (Oerlemans and Fortuin, 1992). Moreover, the $\Delta B / \Delta T$ for the MRB is slightly smaller than Greenland $\left(-0.55 \mathrm{~m}\right.$ w.e. $\left.\mathrm{yr}^{-1}{ }^{\circ} \mathrm{C}^{-1}\right)$, the Tibet $\left(-0.54 \mathrm{~m}\right.$ w.e. $\left.\mathrm{yr}^{-1}{ }^{\circ} \mathrm{C}^{-1}\right)$, Alps $(-0.78 \mathrm{~m}$ w.e. $\left.\mathrm{yr}^{-1}{ }^{\circ} \mathrm{C}^{-1}\right)$ and Iceland (-1.06 m w.e. $\mathrm{yr}^{-1}{ }^{\circ} \mathrm{C}^{-1}$ ) (Radić and Hock, 2011; Braithwaite et al., 2002). The average $\Delta B / \Delta P$ for the MRB is slightly lower than the estimated value $+0.07 \mathrm{~m}$ w.e. $\mathrm{yr}^{-1}(10 \%)^{-1}$ (Braithwaite et al., 2002) in the Tianshan Mountains, the Tibet $(+0.08 \mathrm{~m}$ 


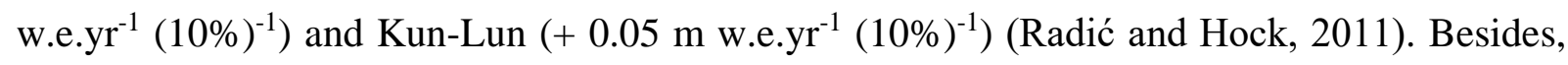
$\Delta B / \Delta T$ is significantly larger than $\Delta B / \Delta P$ in the study area, indicating increased mass balance induced by a $10 \%$ increment in precipitation cannot compensate for the decreased mass balance caused by a $1{ }^{\circ} \mathrm{C}$ temperature rise.

\subsection{The influence of climate change on runoff}

Unevenly distributed discharge in the MRB is very obvious, with approximately $80 \%$ occurring in the melt-season. In this section we are devoted to the impacts of climate change on the melt-season runoff and its key component. To identify the contribution of distinct discharge components, the simulated discharge was separated into glacier runoff (the sum of distinct runoff components over glacier areas) and nonglacier runoff. Then annual distribution of runoff components and the ratio of individual component to the total runoff in the MRB are shown (Figure 5). Obviously, the simulated glacier runoff mainly occurs during the months June-October, characterized by one peak in August. The ratio of monthly glacier streamflow to river discharge is above $40 \%$ in the months July-September, and the largest monthly contribution is up to $60 \%$ in August. These suggest that the glacier runoff is a key runoff component for runoff processes in summer and early autumn.

Due to that the glacier runoff is an important contributor to the melt-season total discharge in the MRB and is highly sensitive to the climate change, it is of necessity to investigate changes in glacier runoff and its contribution to the melt-season total discharge under climate change. As can be seen in Figure 6, because of increased air temperature and precipitation, melt-season total runoff showed a rising trend at $0.72 \mathrm{~mm} \mathrm{a}^{-1}$. Besides, the contribution of glacier runoff to melt-season total runoff ranges from $35 \%$ in 1985 to $64 \%$ in 1997; and non-significantly increased trends are detected for the glacier runoff and its contribution. Similar results were detected in other basins in Tianshan Mountains. In the early studies (Gao et al., 2010; Zhang et al., 2012; Zhao et al., 2015), increasing trends existed for glacier runoff during 1984-2005 in some highly glacierized catchments (like the Yarkant River and Kunma Like river in the Tianshan Mountains), where the contribution of glacier runoff to total runoff is above $50 \%$. In their studies, the glacier runoff is estimated by a 
modified monthly degree-day method or hydrological models.

\subsection{The dependence of runoff on temperature and precipitation}

Figures 7a-7f show the simulated monthly TR (total runoff) and GR (glacier runoff) from 1984 to 2006 for the MRB in comparison to monthly AT (air temperature), PAT (positive accumulated temperature) and $\operatorname{Pr}$ (precipitation). It is evident that there are strong exponential relationships of simulated monthly TR (or GR) with monthly AT. While significant linear relationship with monthly PAT is detected. Besides, PAT is the more sensitive factor to the simulated TR (or GR) compared to Pr. For instance, monthly GA is positively correlated with Pr over the glaciers (significant at the $99 \%$ level), with a correlation coefficient only 0.58 . While a more closed link between the monthly PAT over glaciers and GA is detected, as reflected by a correlation coefficient reaching up to 0.95 (significant at the $99 \%$ level). Based on the correlation relationships between the simulated melt-season GA (or TA) and three climate indexes above (Figures 7g-71), it is found the dominant climate factor for melt-season GA (or TA) is melt-season PAT over glaciers (or over whole basin), followed by melt-season AT and annual Pr over glaciers (or over whole basin).

\section{Discussions}

\subsection{The advantages of the combined IDW and lapse rates method}

In this study, the utilized historical mean air temperature series from Wang et al (2019) was reconstructed by means of the combined IDW and lapse rates method. They found the simulated results are generally satisfactory, considering the limited data points and the spatio-temporal difference of mountainous temperature. In order to further demonstrate the advantages of the combined method in comparison with the lapse rates method regarded as a commonly used method for temperature interpolation in the data-spare region, we evaluate and compare the performance of the above two methods in simulating daily mean temperature. The lapse rates of temperature in different months used in this study are collected from Ji (2013). The skill scores of the analysis by means of cross validation (Zengin, 2014) in several typical stations are shown in Table 2 and Figures $8 \mathrm{a}-8 \mathrm{c}$. The combined method is generally superior to 
the lapse rates method in reconstructing the historical daily mean temperature series during most months, as reflected by higher Nash Sutcliffe efficiency (NSE; Nash,1970) and lower mean absolute error (AME) shown for the combined method. Especially, the combined method significantly improved accuracy of evaluation for daily mean temperature in winter and summer. As shown in Figure 8c displaying simulated and observed daily average temperature during 1985-1987 at Kensiwate station, it is evident daily average air temperature was underestimated in summer and overestimated in winter by the lapse rates method, while a close alignment of the curves based on the observation and simulations by the combined method is identified.

In all, some preliminary results on the reliability of the combined method for interpreting daily mean temperature in data-spare mountainous region are obtained in the present work and Wang et al (2019). Further research as for exploring universality of the combined method through comparing the temperature interpretation error of two methods mentioned above at more data-scarce basins is needed in the future.

\subsection{The effect of different precipitation datasets on the accuracy of hydrological processes modelling}

Precipitation is regarded as one of the important climatic variables in the simulation of discharge. In this study, one precipitation dataset was constructed based on gauged measurements as well as TRMM remote sensing production (termed as GT data) and used for discharge modeling in the MRB where the available gauging data are limited. In order to further demonstrate the advantages of the constructed GT precipitation data in this study in comparison with APHRODITE data (Yatagai and Kawamoto, 2008) regarded as a commonly used precipitation data in the data-spare regions, we tried to evaluate and compare the simulated hydrological processes based on above two precipitation datasets. When hydrological processes were modeled based on APHRODITE precipitation data, the automatic optimization method "SCE-UA" (Duan et al., 1992) was utilized to calibrate parameters of the modified HBV-D model. The streamflow records of Kensiwate hydrological station over the period of 1981-1993 were split into three periods: 1981-1983 for warm-up, 1984-1988 for 
calibration and 1989-1993 for validation. It was found the goodness of fit for daily streamflow simulations based on two precipitation datasets was almost identical in term of the Nash Sutcliffe efficiency(NSE) during 1984-1993, with NSE reaching 0.80 and 0.81 in the case of the simulations based on APHRODITE and GT precipitation data, respectively. As shown in Figure $8 \mathrm{~d}$, the simulated monthly runoff based on GT data showed better agreement with the observations(percent bias $=4.1 \%$ ). Whereas the simulated monthly runoff based on APHRODITE data presented significant underestimations (percent bias $=-13.9 \%$ ) during 1984-1993. In particular the streamflow underestimation was prominent in July and August. In addition, there was a $117.97 \mathrm{~km}^{2}$ decline in the glacier area derived from satellite data in the MRB during the period 1998-2009, when the corresponding glacier area change ratio was $-0.89 \% / a$ (Fan et al., 2015). The simulated annual change ratios in glacier area based on GT and APHRODITE data were $-0.77 \% / \mathrm{a}$ and -0.65\%/a during 1998-2006, respectively. Generally, the constructed GT data in this study can be regarded as a better choice for hydrological processes modelling in the MRB.

\subsection{How do the input uncertainties impact simulations of this study}

In this part, sensitivity tests are conducted to investigate how do the precipitation and air temperature uncertainties impact the simulation of melt-season total runoff, glacier runoff and glacier mass balance in the MRB. As shown in Figure 9, the simulated values are very sensitive to uncertainty in air temperature. When a $1{ }^{\circ} \mathrm{C}$ increase of the air temperature is conducted, MTR (melt-season total runoff), GMA(glacier mass balance) and GA (glacier runoff) will be overestimated by $10 \%, 56 \%$ and $31 \%$. The simulated GMA and GR are less sensitive to uncertainty in precipitation. A $10 \%$ increase or decrease of the input precipitation could induce a $2 \%$ and $7 \%$ underestimation or overestimation in GR and GMB, respectively. Among the above three hydrological indices, MTR is the one with highest sensitivity to uncertainty in precipitation. If the input precipitation is $10 \%$ higher or lower than the precipitation in reference period, MSR will be overestimated or underestimated by $10 \%$.

\section{Conclusions}


The study aimed to identify variation characteristics for glacier mass balance as well as runoff components during 1984-2006 and their dependence on climate indexes in the MRB featured by a glaciated high-mountainous catchment. A hydrological modeling framework based on the modified HBV-D model was applied. The response of glacier mass balance and runoff components to climate change is estimated on the basis of model simulations. The main findings are shown as follows:

(1) In term of percent bias between the simulated glacier volume change from HBV-D and the modified ones, snow/glacier melt method made more contribution to advance the ability of HBV-D model to compute historical glacier volume change, followed by the glacier dynamic method.

(2) The reconstructed mass balance shows a decreased trend during 1984-2006 in the MRB. Changes in mass balance induced by a $10 \%$ increase in precipitation and a $1{ }^{\circ} \mathrm{C}$ temperature rise are $+0.04 \mathrm{~m}$ w.e. $\mathrm{yr}^{-1}(10 \%)^{-1}$ and $-0.41 \mathrm{~m}$ w.e. $\mathrm{yr}^{-1}{ }^{\circ} \mathrm{C}^{-1}$, respectively. These indicate that mass balance in the MRB was more sensitive to temperature change than to precipitation change. Besides, the sensitivity of mass balance to temperature change in the study region is smaller than those of Greenland, the Tibet, Alps and Iceland.

(3) The runoff in glacierized area accounts for $41.5 \%$ of the melt-season total discharge in the MRB. The melt-season PAT over the glaciers exerts more influence on the change in glacier runoff than melt-season AT. In addition, general increase trends are detected for the glacier runoff and its contribution to melt-season total runoff. This finding suggests increased glacier runoff is having a growing influence on melt-season water resources in the study area. However, glacier retreat would cause a reduction in glacier runoff in the longer term, potentially affecting the availability of regional water resource. Hence further research as for assessing future hydrological change including glacier mass loss and glacier runoff change is needed in the future.

\section{ACKNOWLEDGEMENTS}

Funding: The work was jointly supported by grants from the National Natural Science Foundation of China (41807149, 51879068, 41561134016), National Key Research and Development Program 
(2018YFC0407900), China Postdoctoral Science Foundation (2017M621616) and Open Research Fund Program of State Key Laboratory of Water Resources and Hydropower Engineering Science (2017SWG03)

Conflicts of Interest: The authors declare no conflict of interest

\section{References:}

Aizen, V.B., Aizen, E.M. and Kuzmichonok, V.A., 2007a. Glaciers and hydrological changes in the Tien Shan: simulation and prediction. Environmental Research Letters, 2(4): 045019.

Aizen, V.B., Aizen, E.M., Melack, J.M. and Dozier, J., 1997. Climatic and Hydrologic Changes in the Tien Shan, Central Asia. Journal of Climate, 10(6): 1393-1404.

Aizen, V.B., Kuzmichenok, V.A., Surazakov, A.B. and Aizen, E.M., 2007b. Glacier changes in the Tien Shan as determined from topographic and remotely sensed data. Global and Planetary Change, 56(3): 328-340.

Arnold, N.S., Willis, I.C., Sharp, M.J., Richards, K.S. and Lawson, W.J., 1996. A distributed surface energy-balance model for a small valley glacier. I. Development and testing for Haut Glacier d' Arolla, Valais, Switzerland., 42(140): 77-89.

Bergstrom, S., 1992. The HBV Model: Its Structure and Applications, Swedish Meteorological and Hydrological Institute (SMHI), Hydrology. Norrköping.

Bitz, C.M. and Battisti, D.S., 1999. Interannual to Decadal Variability in Climate and the Glacier Mass Balance in Washington, Western Canada, and Alaska. Journal of Climate, 12(11): 3181-3196.

Braithwaite, R.J. and Zhang, Y., 1999. Modelling changes in glacier mass balance that may occur as a result of climate changes. Geografiska Annaler: Series A, Physical Geography, 81(4): 489-496.

Braithwaite, R.J., Zhang, Y. and Raper, S.C.B., 2002. Temperature sensitivity of the mass balance of mountain glaciers and ice caps as a climatological characteristic. Zeitschrift fur Gletscherkunde und Glazialgeologie, 38(1): 35--61.

Brunetti, M.T., Melillo, M., Peruccacci, S., Ciabatta, L. and Brocca, L., 2018. How far are we from the use of satellite rainfall products in landslide forecasting? Remote Sensing of Environment, 210: 65-75.

Chen, J. and Ohmura, A., 1990. Estimation of alpine glacier water resources and their change since the 1870s. Hydrology in mountainous regions - I. Hydrologic measurements, the water cycle. In: Proceedings of the Two Lausanne Symposia, IAHS Publ., 127 - 135 pp. 
Cui, T.,Yang, T., Xu, C-Y., Shao, Q., Wang, X., Li, Z. (2018). Assessment of the impact of climate change on flow regime at multiple temporal scales and potential ecological implications in an alpine river. Stoch Environ Res Risk Assess, 32(6): 1849-1866, doi:10.1007/s00477-017-1475-z.

Duan, Q., Sorooshian, S. and Gupta, V., 1992. Effective and efficient global optimization for conceptual rainfall-runoff models. Water Resources Research, 28(4): 1015-1031.

Fan, X. et al., 2015. Analysis of glacier change in Manas River basin in the last 50 years based on multi-source data. Journal of Glaciology and Geocryology, 37(05): 1188-1198(In Chinese).

Ficklin, D.L., Luo, Y. and Zhang, M., 2012. Watershed modelling of hydrology and water quality in the Sacramento River watershed, California. Hydrological Processes, 27(2): 236-250.

Gao, H., He, X., Ye, B. and Pu, J., 2012. Modeling the runoff and glacier mass balance in a small watershed on the Central Tibetan Plateau, China, from 1955 to 2008. Hydrological Processes, 26(11): 1593-1603.

Gao, X., Ye, B., Zhang, S., Qiao, C. and Zhang, X., 2010. Glacier runoff variation and its influence on river runoff during 1961 - 2006 in the Tarim River Basin, China. Science China Earth Sciences, 53(6): 880-891.

Gupta, H.V., Sorooshian, S. and Yapo, P.O., 1999. Status of Automatic Calibration for Hydrologic Models: Comparison with Multilevel Expert Calibration. Journal of Hydrologic Engineering, 4(2): 135-143.

Hagg, W., Braun, L.N., Kuhn, M. and Nesgaard, T.I., 2007. Modelling of hydrological response to climate change in glacierized Central Asian catchments. Journal of Hydrology, 332(1): 40-53.

Han, T., Ding, Y., Ye, B., Liu, S. and Jiao, K., 2006. Mass-balance characteristics of Ürümqi glacier No. 1, Tien Shan, China. Annals of Glaciology, 43: 323-328.

Hargreaves, G.H., 1975. Moisture Availability and Crop Production. Transactions of the ASAE, 18(5): 980.

Hock, R., 1999. A distributed temperature-index ice- and snowmelt model including potential direct solar radiation. Journal of Glaciology, 45(149): 101-111.

Hock, R., 2003. Temperature index melt modelling in mountain areas. Journal of Hydrology, 282(1): 104-115.

Hock, R., 2005. Glacier melt: a review of processes and their modelling. Progress in Physical Geography, 29(3): 362-391.

Huang, C., Yang, T., Yeh, H., (2018), Review of analytical models to stream depletion induced by pumping: Guide to model selection, Journal of Hydrology, 561: 277-285, doi: 10.1016/j.jhydrol.2018.04.015.

Huss, M., Bauder, A., Funk, M. and Hock, R., 2008a. Determination of the seasonal mass balance of four Alpine glaciers since 1865. Journal of Geophysical Research: Earth Surface, 113(F1). 
Huss, M., Farinotti, D., Bauder, A. and Funk, M., 2008b. Modelling runoff from highly glacierized alpine drainage basins in a changing climate. Hydrological Processes, 22(19): 3888-3902.

Immerzeel, W.W., van Beek, L.P.H., Konz, M., Shrestha, A.B. and Bierkens, M.F.P., 2012. Hydrological response to climate change in a glacierized catchment in the Himalayas. Climatic Change, 110(3): 721-736.

Ismail, M.F. and Bogacki, W., 2018. Scenario approach for the seasonal forecast of Kharif flows from the Upper Indus Basin. Hydrology and Earth System Sciences, 22(2): 1391--1409.

Jarvis, A., H.I. Reuter, A. Nelson, E. Guevara, 2008, Hole-filled SRTM for the globe Version 4, available from the CGIAR-CSI SRTM 90m Database.

Ji, X. 2013.The Simulation Study of Snow and Glacier Runoff Processes in Manas River Basin, Northwest China. $\mathrm{PhD}$ Thesis.Xinjiang Institute of Ecology and Geography, Chinese Academy of Sciences.

Ji, X. and Chen, Y., 2012. Characterizing spatial patterns of precipitation based on corrected TRMM 3B43 data over the mid Tianshan Mountains of China. Journal of Mountain Science, 9(5): 628-645.

Jia, Y. et al., 2006. Development of the WEP-L distributed hydrological model and dynamic assessment of water resources in the Yellow River basin. Journal of Hydrology, 331(3): 606-629.

Jiang, L. et al., 2015. Analysis on the Trend of Climate and Runoff Changes of Manas River Basin Upstream. Environmental Protection of Xinjiang, 37(04): 13-19 (In Chinese).

Jiang, S. et al., 2012. Comprehensive evaluation of multi-satellite precipitation products with a dense rain gauge network and optimally merging their simulated hydrological flows using the Bayesian model averaging method. Journal of Hydrology, 452-453(Supplement C): 213-225.

Jiang, X., Wang, N., He, J., Wu, X. and Song, G., 2010. A distributed surface energy and mass balance model and its application to a mountain glacier in China. Chinese Science Bulletin, 55(20): 2079-2087.

Jiang, Y. A., Yang, A., and Zhao, Y.Z et al. 2013. Analysis on changes of basic climatic elements and extreme events in Xinjiang, China during 1961-2010. Advances in Climate Change Research, 4(1), 20-29.

Krakauer, Y.N., Pradhanang, M.S., Lakhankar, T. and Jha, K.A., 2013. Evaluating Satellite Products for Precipitation Estimation in Mountain Regions: A Case Study for Nepal., 5(8).

Krause, P., 2002. Quantifying the impact of land use changes on the water balance of large catchments using the J2000 model. Physics and Chemistry of the Earth, Parts A/B/C, 27(9): 663-673.

KRYSANOVA, V., BRONSTERT, A. and MÜLLER-WOHLFEIL, D.I., 1999. Modelling river discharge for large drainage basins: from lumped to distributed approach. Hydrological Sciences Journal, 44(2): 313-331. 
Kumar, R. et al., 2016. Development of a Glacio-hydrological Model for Discharge and Mass Balance Reconstruction. Water Resources Management, 30(10): 3475-3492.

Kumar, A., Yang, T., Sharma, M.P. Long-term prediction of greenhouse gas risk to the Chinese hydropower reservoirs. Science of the Total Environment, 2019, 646, 300-308.

Li, H. et al., 2015. Integrating a glacier retreat model into a hydrological model - Case studies of three glacierised catchments in Norway and Himalayan region. Journal of Hydrology, 527: 656-667.

Li, X., Toshio, K. and Cheng, G., 2002. Retrieval of snow reflectance from Landsat data in rugged terrain., 34: 31-37.

Li, Z.Y. Yang, T. Huang, C.S. et al., 2018. An improved approach for water quality evaluation: TOPSIS-based informative weighting and ranking (TIWR) approach. Ecological Indicators, 89: 356-364.

Lin, J., Feng, X., Xiao, P. and Li, H., 2011. Inner-annual variation of snow cover in mountainous area of Manas river basin based on MODIS. Arid Land Geography, 34(06): 975-982(In Chinese).

Liu, L.L., Fischer, T. and Jiang, T et al. 2013. Comparison of uncertainties in projected flood frequency of the Zhujiang River, South China, Quaternary International,304,51-61.

Liu, Q. and Liu, S., 2016. Response of glacier mass balance to climate change in the Tianshan Mountains during the second half of the twentieth century. Climate Dynamics, 46(1): 303-316.

Liu, S., Wenxin, S., Yongping, S. and Gang, L., 2003. Glacier changes since the Little Ice Age maximum in the western Qilian Shan, northwest China, and consequences of glacier runoff for water supply., 49(164): $117-124$.

Luo, Y., Arnold, J., Liu, S., Wang, X. and Chen, X., 2013. Inclusion of glacier processes for distributed hydrological modeling at basin scale with application to a watershed in Tianshan Mountains, northwest China. Journal of Hydrology, 477(Supplement C): 72-85.

Menzel, L., and Bürger, G. 2002. Climate change scenarios and runoff response in the Mulde catchment (Southern Elbe, Germany), Journal of Hydrology, 267(1-2) ,53-64.

Menzel, L., Thieken, A.H., Schwandt, D. et al. 2006. Impact of Climate Change on the Regional Hydrology Scenario-Based Modelling Studies in the German Rhine Catchment. Nat Hazards 38, 45-61.

Moriasi, D.N., Gitau, M. and Pai, N., 2015. Hydrologic and Water Quality Models: Performance Measures and Evaluation Criteria. Transactions of the ASABE, 58(6): 1763-1785.

Narama, C., Kääb, A., Duishonakunov, M. and Abdrakhmatov, K., 2010. Spatial variability of recent glacier area 
changes in the Tien Shan Mountains, Central Asia, using Corona ( 1970), Landsat ( 2000), and ALOS ( 2007) satellite data. Global and Planetary Change, 71(1): 42-54.

Nash, J.E. and Sutcliffe, J.V., 1970. River flow forecasting through conceptual models part I - A discussion of principles. Journal of Hydrology, 10(3): 282-290.

Oerlemans, J. and Fortuin, J.P.F., 1992. Sensitivity of Glaciers and Small Ice Caps to Greenhouse Warming. Science, 258(5079): 115 .

Pellicciotti, F. et al., 2005. An enhanced temperature-index glacier melt model including the shortwave radiation balance: development and testing for Haut Glacier d' Arolla, Switzerland. Journal of Glaciology, 51(175): 573-587.

Pellicciotti, F. et al., 2008. A study of the energy balance and melt regime on Juncal Norte Glacier, semi-arid Andes of central Chile, using melt models of different complexity. Hydrological Processes, 22(19): 3980-3997.

Pritchard, H. D. (2017). Asia's glaciers are a regionally important buffer against drought. Nature, 545(7653), $169-174$.

Qin, Y.W, Kavetski, D, and Kuczera, George. 2018a. A Robust Gauss-Newton Algorithm for the Optimization of Hydrological Models: From Standard Gauss-Newton to Robust Gauss-Newton, Water Resources Research, DOI: $10.1029 / 2017$ WR022488.

Qin, Y.W, Kavetski, D, and Kuczera, George. 2018b. A Robust Gauss-Newton Algorithm for the Optimization of Hydrological Models: Benchmarking against Industry-Standard Algorithms, Water Resources Research, DOI: $10.1029 / 2017$ WR022489.

Radić, V. and Hock, R., 2006. Modeling future glacier mass balance and volume changes using ERA-40 reanalysis and climate models: A sensitivity study at Storglaciären, Sweden. Journal of Geophysical Research: Earth Surface, 111(F3).

Radić, V. and Hock, R., 2011. Regionally differentiated contribution of mountain glaciers and ice caps to future sea-level rise. Nature Geoscience, 4: 91-94.

Ren, W., Yang, T., Shi, P., Xu, C-Y., Zhang, K., Zhou, X., Shao, Q., Ciais, P. (2018). A probabilistic method for streamflow projection and associated uncertainty analysis in a data sparse alpine region. Global \& Planetary Change, doi:10.1016/j.gloplacha.2018.03.011. 
RGI Consortium .2013. Randolph Glacier Inventory - A Dataset of Global Glacier Outlines: Version 3.2: Technical Report, Global Land Ice Measurements from Space, Colorado, USA. Digital Media. DOI: https://doi.org/10.7265/N5-RGI-32.

Schaefli, B., Hingray, B., Niggli, M. and Musy, A., 2005. A conceptual glacio-hydrological model for high mountainous catchments. Hydrol. Earth Syst. Sci., 9(1/2): 95-109.

Schaper, J., Martinec, J. and Seidel, K., 1999. Distributed mapping of snow and glaciers for improved runoff modelling. Hydrological Processes, 13(12 - 13): 2023-2031.

Shen, Y., Shen, Y., Fink, M., Kralisch, S. and Brenning, A., 2018. Unraveling the Hydrology of the Glacierized Kaidu Basin by Integrating Multisource Data in the Tianshan Mountains, Northwestern China. Water Resources Research, 54(1): 557-580.

Shi, PF., Yang, T., Xu CY et al. 2017. How Do the Multiple Large-Scale Climate Oscillations Trigger Extreme Precipitation?, Global and Planetary Change, Vol.157, pp: 48-58.

Shi, P. et al., 2016. Response of Xiao Dongkemadi Glacier in the central Tibetan Plateau to the current climate change and future scenarios by 2050. Journal of Mountain Science, 13(1): 13-28.

Sorg, A., Bolch, T., Stoffel, M., Solomina, O. and Beniston, M., 2012. Climate change impacts on glaciers and runoff in Tien Shan (Central Asia). Nature Climate Change, 2: 725-731.

Stampoulis, D. and Anagnostou, E.N., 2012. Evaluation of Global Satellite Rainfall Products over Continental Europe. Journal of Hydrometeorology, 13(2): 588-603.

Sun, C. et al., 2016. Comparative study of streamflow components in two inland rivers in the Tianshan Mountains, Northwest China. Environmental Earth Sciences, 75(9): 727.

Tennant, C.J. et al., 2017. Regional sensitivities of seasonal snowpack to elevation, aspect, and vegetation cover in western North America. Water Resources Research, 53: 6908-6926.

Thiemig, V., Rojas, R., Zambrano-Bigiarini, M., Levizzani, V. and De Roo, A., 2012. Validation of Satellite-Based Precipitation Products over Sparsely Gauged African River Basins. Journal of Hydrometeorology, 13(6): 1760-1783.

Van Tiel, M. et al., 2018. The role of glacier changes and threshold definition in the characterisation of future streamflow droughts in glacierised catchments. Hydrology and Earth System Sciences, 22(1): 463--485.

Wang, X., Luo, Y., Sun, L. and Zhang, Y., 2015. Assessing the effects of precipitation and temperature changes on hydrological processes in a glacier-dominated catchment. Hydrological Processes, 29(23): 4830-4845. 
Wang, X.,Yang,T.,Yong,B.,Krysanova,V., et al .2018. Impacts of climate change on flow regime and sequential threats to riverine ecosystem in the source region of the Yellow River. Environmental Earth Sciences, 77(12): 465 .

Wang, X., Yang, T., Wortmann, M., Shi, P., Hattermann, F., \& Lobanova, A., et al. (2017). Analysis of multi-dimensional hydrological alterations under climate change for four major river basins in different climate zones. Climatic Change, 141, 1-16.

Wang, X., Yang, T., Xu, C.Y., et al. 2019. Understanding the discharge regime of a glacierized alpine catchment in the Tianshan Mountains using an improved HBV-D hydrological model. Global and Planetary Change.172, 211-222.

Xing, W., Li, Z. and Zhang, H., 2017. Spatial-temporal variation of glacier resources in Chinese Tianshan Mountains since 1959. ACTA GEOGRAPHICA SINICA, 72(9): 1594-1605.(In Chinese)

Xu, M., Wu, H. and Kang, S., 2018. Impacts of climate change on the discharge and glacier mass balance of the different glacierized watersheds in the Tianshan Mountains, Central Asia. Hydrological Processes, 32(1): $126-145$

Yang, H., Li, Z., Ye, B., Jiao, K. and Jing, Z., 2005. Study on Mass Balance and Process of Glacier No.1 at the Headwaters of the Urumqi River in the Past 44 Years. ARID LAND GEOGRAPHY(01): 76-80.

Yang, T. et al., 2014. Climate change and probabilistic scenario of streamflow extremes in an alpine region. Journal of Geophysical Research: Atmospheres, 119(14): 8535-8551.

Yang, T. and Cui, T., Xu, C.Y, et al. 2017. Development of a New Iha Method for Impact Assessment of Climate Change on Flow Regime, Global and Planetary Change,156, 68-79.

Yatagai, A. and Kawamoto, H., 2008. Quantitative estimation of orographic precipitation over the Himalayas by using TRMM/PR and a dense network of rain gauges. Proceedings of SPIE, 7148.

Zemp, M., and Coauthors, 2013: Reanalysing glacier mass balance measurement series. Cryosphere, 7, 1227-1245, doi:10.5194/tc-7-1227-2013.

Zengin K.S., 2014. A study for applications of spatial interpolation methods: case study for daily mean temperature data of Black Sea Region of Turkey, Master of Science Thesis, Thesis Supervisor: Emine Tanır Kayıkçı, Karadeniz Technical University, Natural Science Institute, 2014, Trabzon, Turkey (in Turkish)

Zhang, S., Ye, B., Liu, S., Zhang, X. and Hagemann, S., 2012. A modified monthly degree-day model for evaluating glacier runoff changes in China. Part I: model development. Hydrological Processes, 26(11): 
1686-1696.

Zhang, Y. et al., 2017. Glacier mass balance and its potential impacts in the Altai Mountains over the period 1990 - 2011. Journal of Hydrology, 553: 662-677.

Zhang, Z., Li, Z. and He, X., 2014. Progress in the research on glacial change and water resources in Manas river basin. Research of soil and water conservation, 5(21): 332-337.(In Chinese)

Zhao, Q. et al., 2015. Modeling Hydrologic Response to Climate Change and Shrinking Glaciers in the Highly Glacierized Kunma Like River Catchment, Central Tian Shan. Journal of Hydrometeorology, 16(6): 2383-2402. 


\section{Tables}

Table 1 Three versions of the modified HBV-D model (Wang et al., 2019)

\begin{tabular}{lccc}
\hline & HBV-D1 & HBV-D2 & HBV-D3 \\
\hline $\begin{array}{c}\text { 1.Modification in the spatial } \\
\text { discretization }\end{array}$ & $\sqrt{ }$ & $\sqrt{ }$ & $\sqrt{ }$ \\
$\begin{array}{c}\text { 2.Modification in the } \\
\text { snow/glacier melt method } \\
\text { 3.considering the glacier } \\
\text { dynamic }\end{array}$ & & $\sqrt{ }$ & $\sqrt{ }$ \\
\hline
\end{tabular}

Note: “ $\sqrt{ }$ "denotes the modified element included in the hydrological model 
Table 2 The performance evaluations for the temperature lapse rate method (TLR) and the combined method in three typical stations during the period 1984-2006

Note: MAE is mean absolute error, NSE is the Nash Sutcliffe efficiency

\begin{tabular}{|c|c|c|c|c|c|c|c|c|c|c|c|c|}
\hline \multirow[b]{3}{*}{ Month } & \multicolumn{4}{|c|}{ Wulan } & \multicolumn{4}{|c|}{ Hutubi } & \multicolumn{4}{|c|}{ Wulumuqi } \\
\hline & \multicolumn{2}{|c|}{$\operatorname{MAE}\left({ }^{\circ} \mathrm{C}\right)$} & \multicolumn{2}{|r|}{ NSE } & \multicolumn{2}{|c|}{$\operatorname{MAE}\left({ }^{\circ} \mathrm{C}\right)$} & \multicolumn{2}{|c|}{ NSE } & \multicolumn{2}{|c|}{$\operatorname{MAE}\left({ }^{\circ} \mathrm{C}\right)$} & \multicolumn{2}{|r|}{ NSE } \\
\hline & TLR & Combined & TLR & Combined & TLR & Combined & TLR & Combined & TLR & Combined & TLR & Combined \\
\hline Jan & 2.15 & 1.97 & 0.72 & 0.77 & 2.15 & 2.25 & 0.74 & 0.75 & 2.37 & 1.94 & 0.61 & 0.73 \\
\hline Feb & 2.41 & 2.07 & 0.77 & 0.84 & 2.41 & 2.58 & 0.77 & 0.78 & 2.17 & 1.85 & 0.73 & 0.81 \\
\hline Mar & 1.61 & 1.21 & 0.9 & 0.95 & 1.61 & 1.34 & 0.91 & 0.95 & 1.39 & 1.21 & 0.9 & 0.92 \\
\hline Apr & 1.08 & 0.9 & 0.93 & 0.95 & 1.08 & 0.71 & 0.92 & 0.97 & 1.52 & 1.16 & 0.86 & 0.91 \\
\hline May & 1.12 & 0.93 & 0.89 & 0.92 & 1.12 & 0.72 & 0.89 & 0.96 & 1.64 & 1.19 & 0.79 & 0.88 \\
\hline Jun & 1.16 & 0.96 & 0.84 & 0.9 & 1.16 & 0.84 & 0.85 & 0.93 & 1.49 & 1.07 & 0.76 & 0.86 \\
\hline Jul & 1.09 & 1.01 & 0.79 & 0.81 & 1.09 & 0.75 & 0.79 & 0.9 & 1.6 & 1.21 & 0.62 & 0.75 \\
\hline Aug & 1.05 & 1.14 & 0.83 & 0.81 & 1.05 & 0.81 & 0.84 & 0.91 & 1.72 & 1.34 & 0.62 & 0.76 \\
\hline Sep & 1.02 & 1.1 & 0.9 & 0.88 & 1.02 & 0.8 & 0.9 & 0.94 & 1.53 & 1.4 & 0.78 & 0.82 \\
\hline Oct & 1.07 & 0.95 & 0.91 & 0.93 & 1.07 & 0.7 & 0.91 & 0.96 & 1.6 & 1.41 & 0.81 & 0.85 \\
\hline Nov & 1.56 & 1.37 & 0.85 & 0.89 & 1.56 & 1.16 & 0.88 & 0.94 & 1.61 & 1.26 & 0.85 & 0.9 \\
\hline Dec & 1.95 & 1.8 & 0.86 & 0.88 & 1.95 & 1.94 & 0.87 & 0.89 & 2.35 & 2.2 & 0.71 & 0.74 \\
\hline
\end{tabular}




\section{Figures}

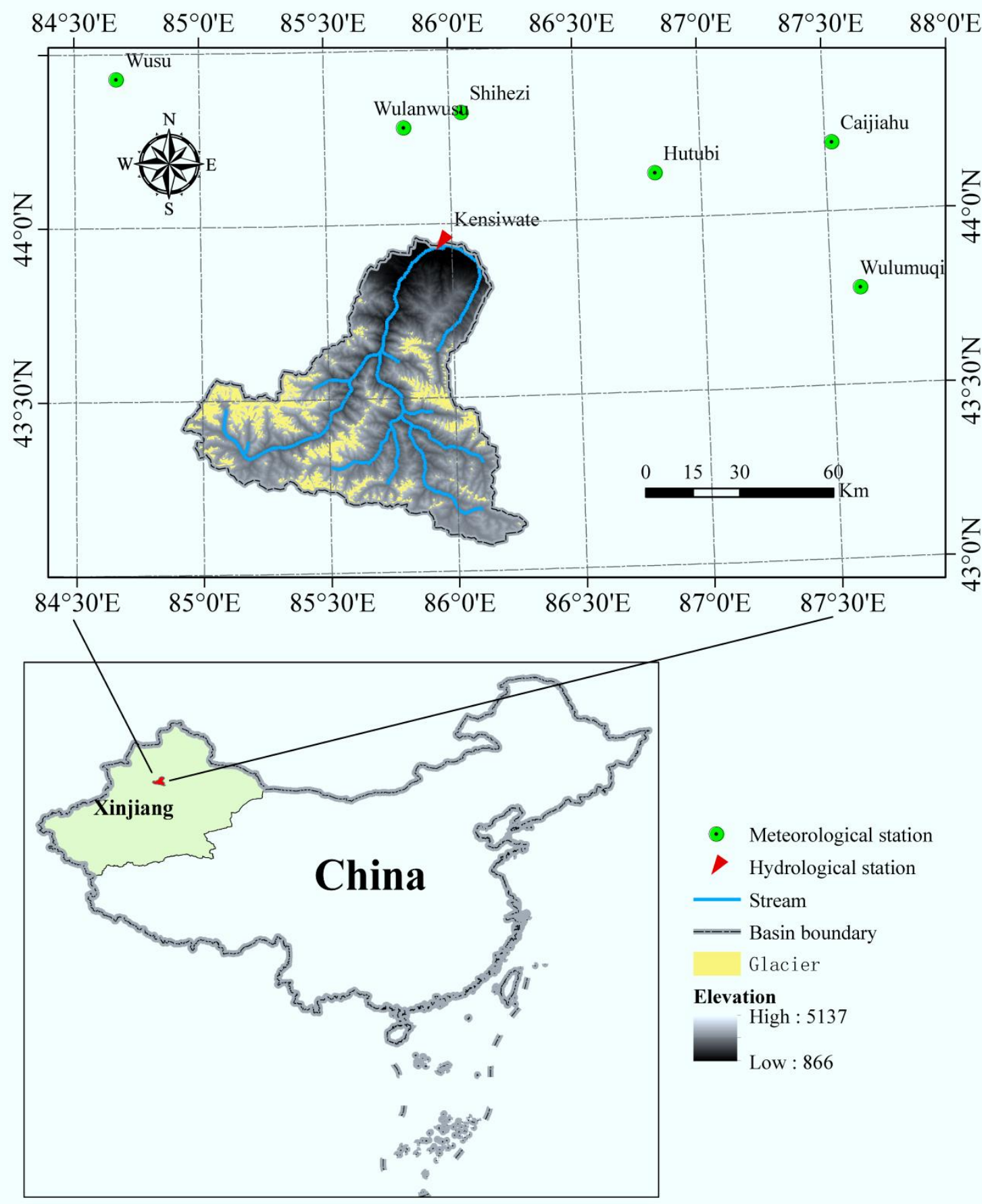

Figure 1 Map of the alpine source region of Manas River Basin (MRB) in the Tianshan Mountains 


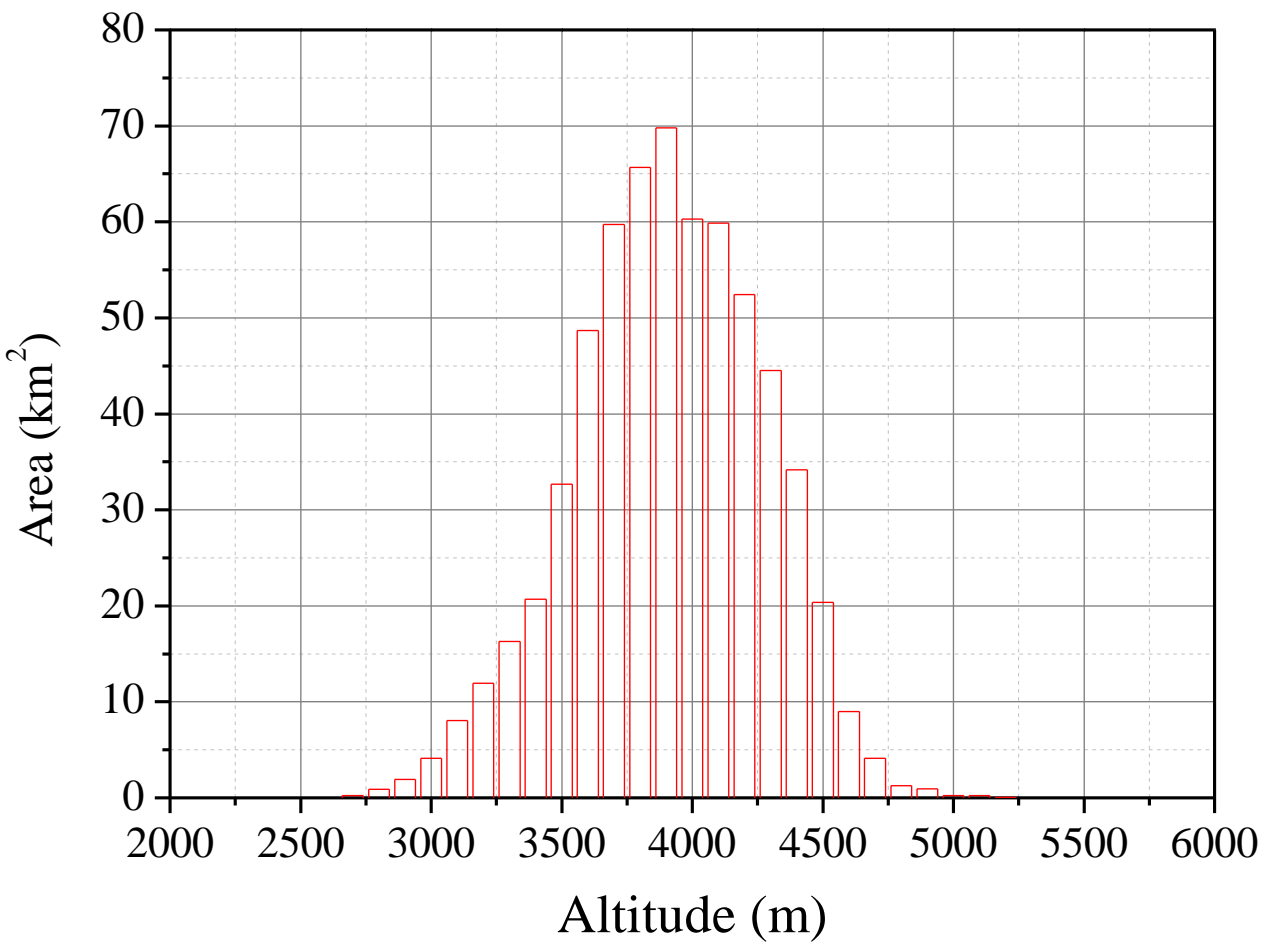

Figure 2 Plot of glacier area in relation to altitude in the Manas River Basin 

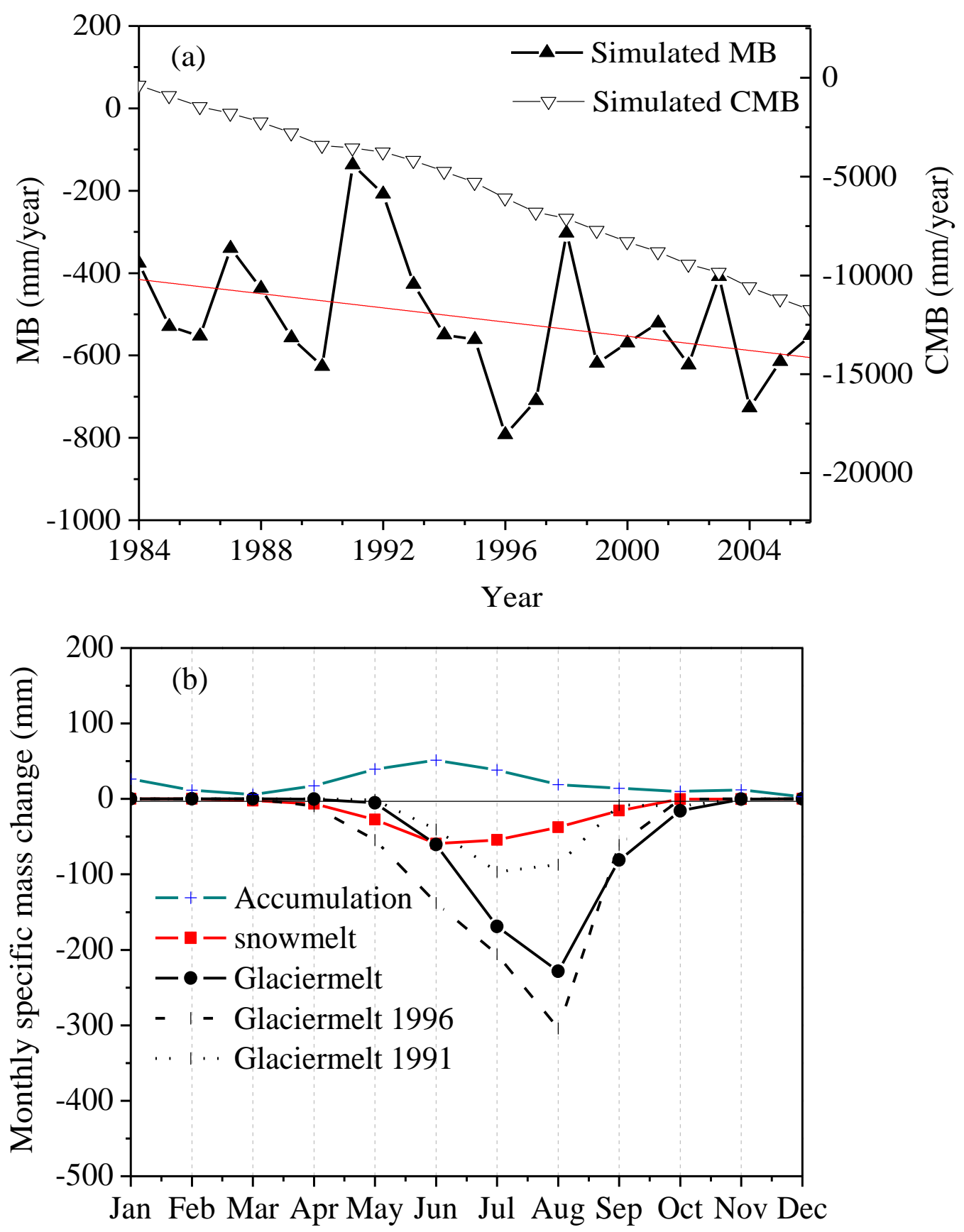

Figure 3 (a) Variations of annual and cumulative glacier mass balances for the MRB during 1984/85-2006/07 and (b) monthly components of glacier mass balance (accumulation/solid precipitation, snowmelt, glaciermelt) as a mean over 1984-2006. Glacier melt for the extreme years of 1991 (cold and wet summer) and 1996 (hot, dry) is also included. MB denotes glacier mass balance; and CMB is cumulative glacier mass balance. 

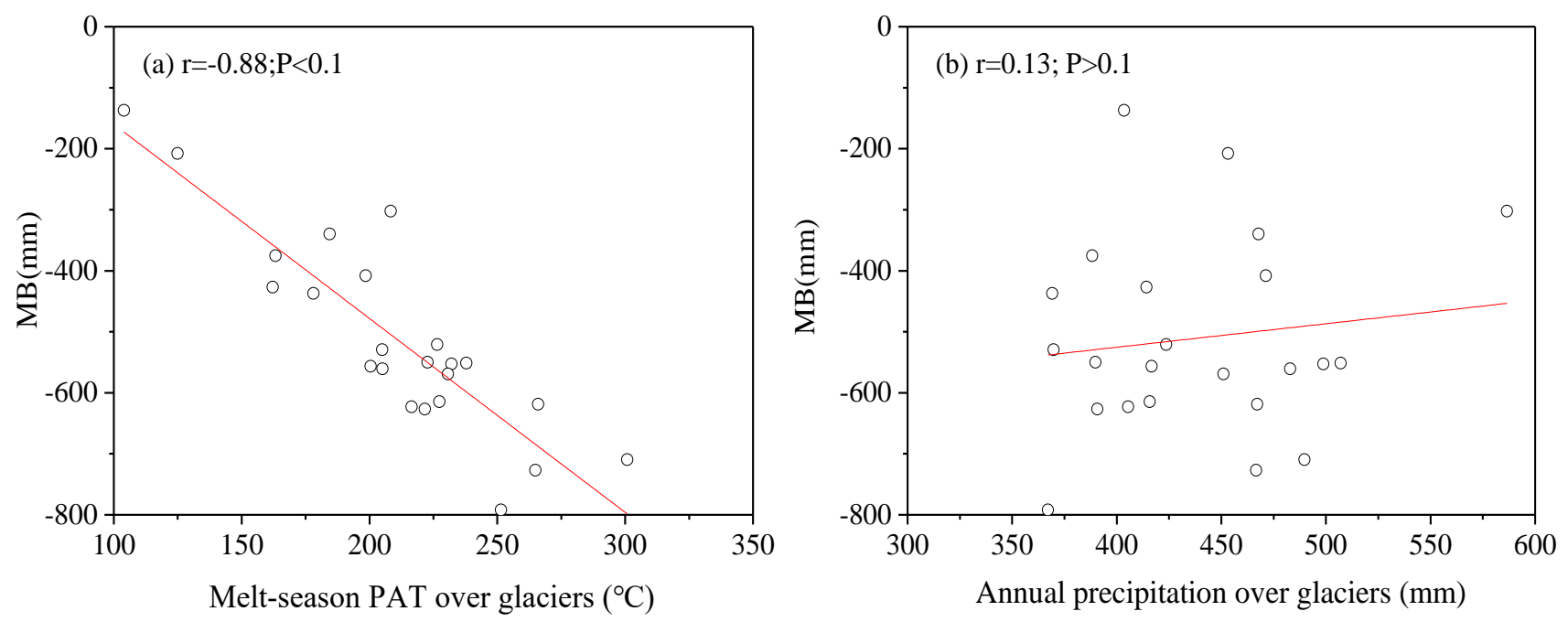

Figure 4 Linear correlations between annual glacier mass balance and (a) melt-season PAT as well as (b) annual precipitation over glaciers. Here PAT represents positive accumulated temperature. The value of $\mathrm{P}$ is used to identify the statistical significance. 

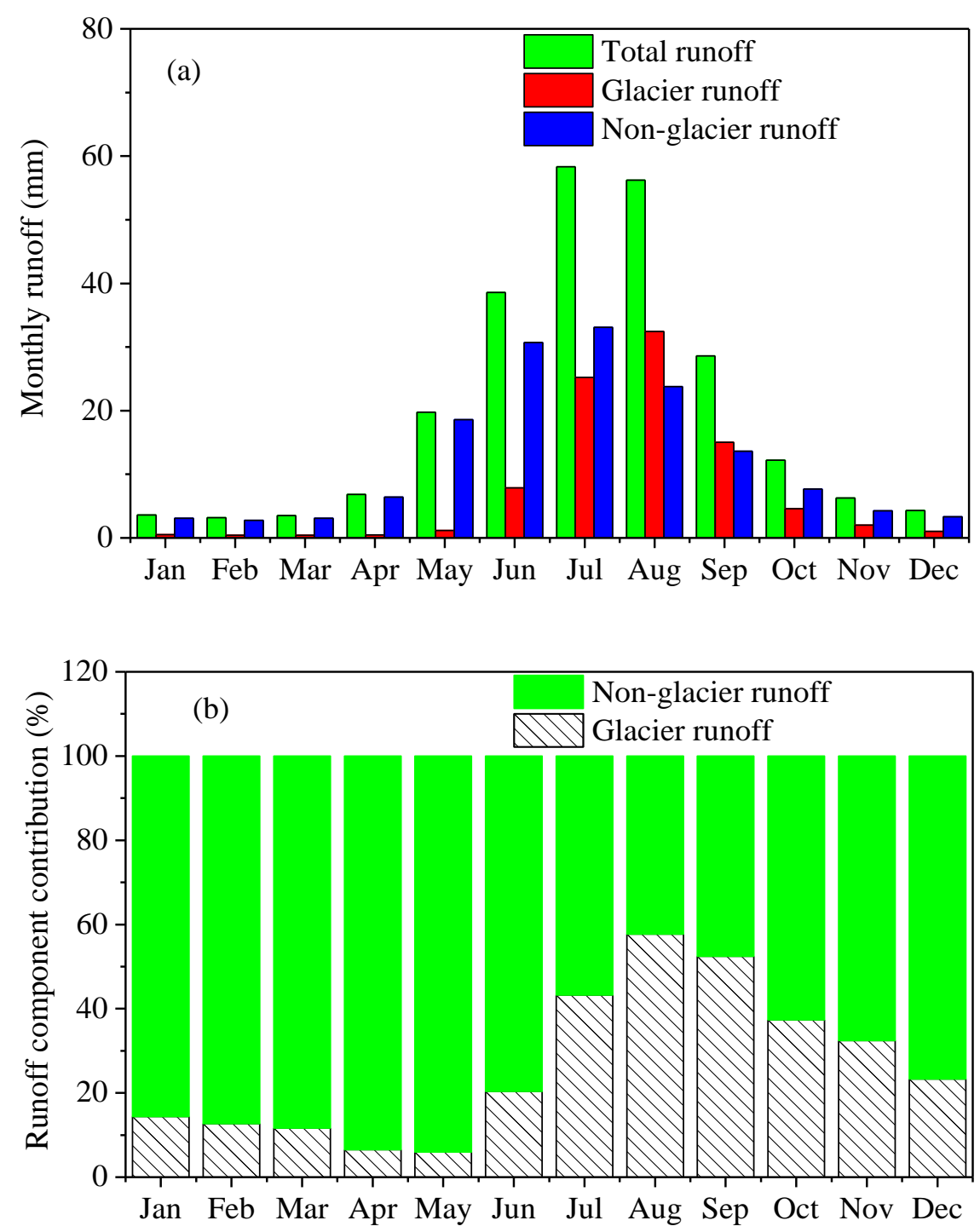

Figure 5 (a) Annual distribution of runoff components (runoff in glacier area and in non-glacier area) and (b) the ratio of individual component to the river discharge for the MRB 
(a)

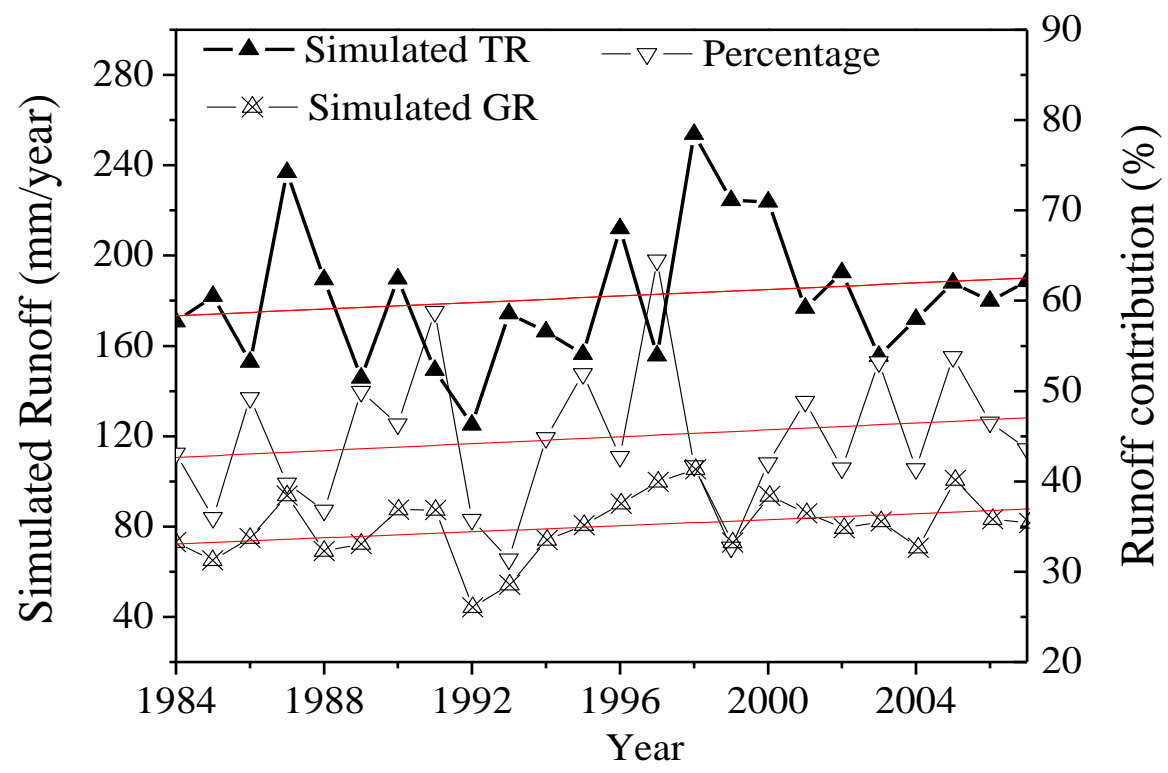

(b)

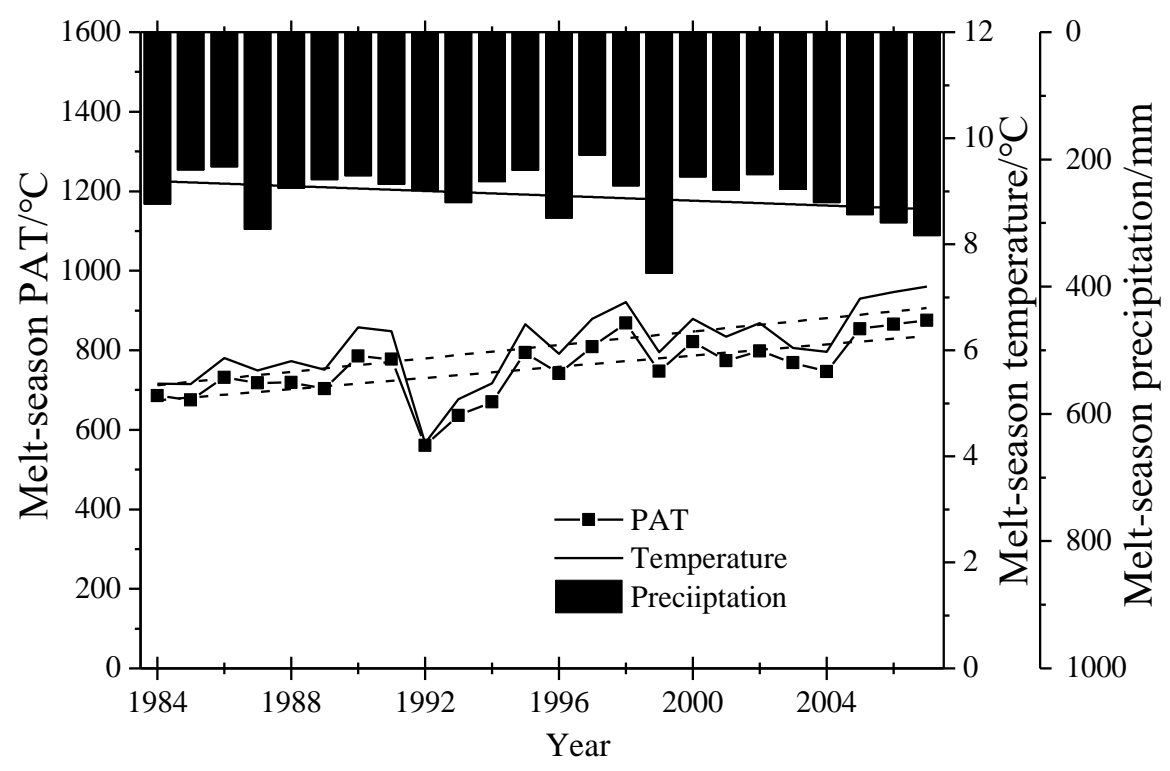

Figure 6 Simulated melt-season (a) runoff, glacier runoff, as well as glacier runoff contribution and (b) precipitation, air temperature and PAT in the MRB during 1984-2006. Straight lines are fitted for each variable. Dotted line indicates that the trend is significant. PAT denotes positive accumulated temperature. 

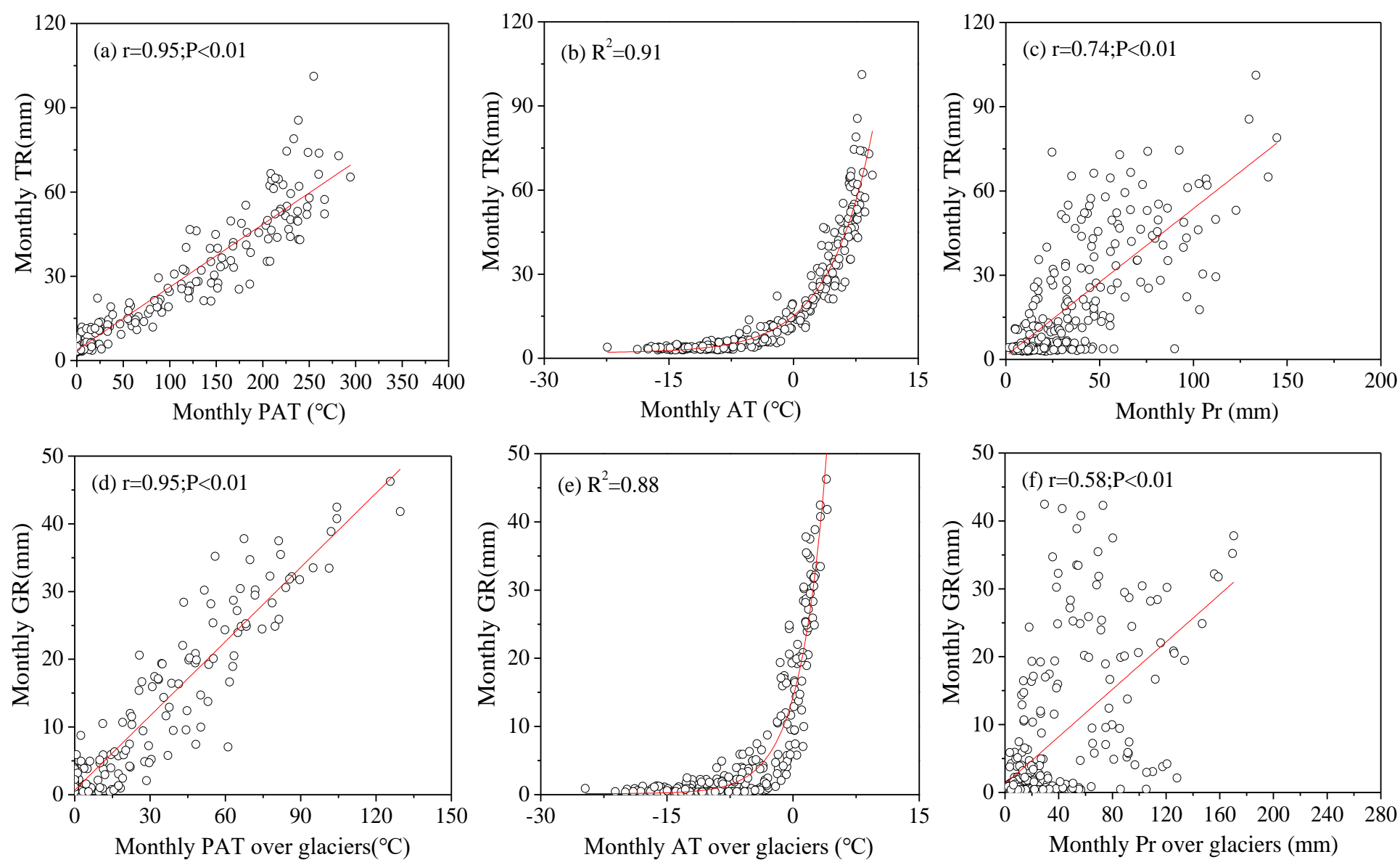

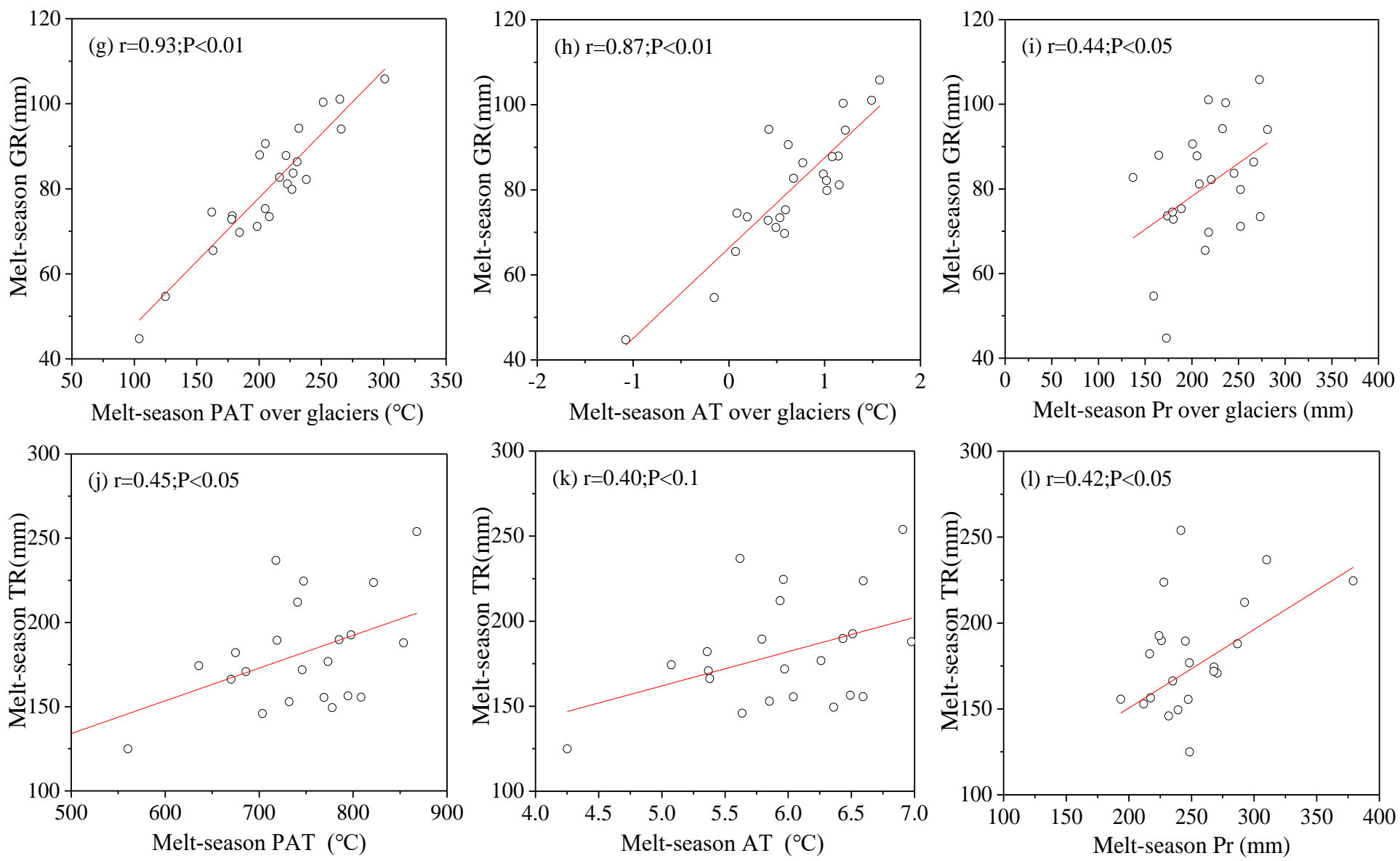

Figure 7 Relationships between total/glacier runoff (TR/GR) in different time scales (monthly and melt-season) and three climate index (PAT, AT and Pr). PAT represents positive accumulated temperature. AT is air temperature. Pr denotes precipitation. In each figure $r$ represents correlation coefficient. The value of $\mathrm{P}$ is used to identify the statistical significance. $\mathrm{R}^{2}$ represents coefficient of determination. 

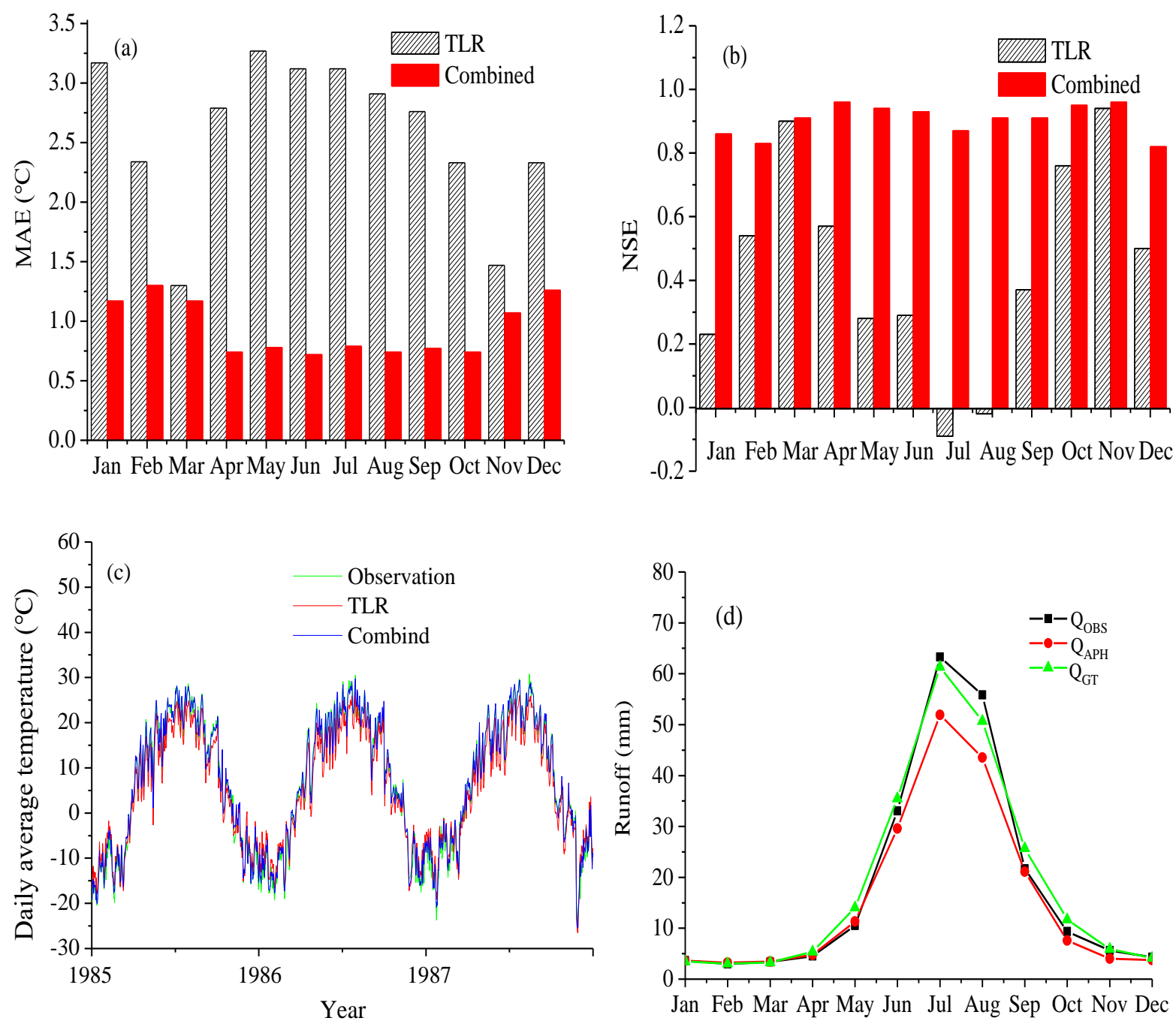

Figure 8 Evaluating the performance of two temperature interpolation methods in simulating daily mean temperature at Kensiwate station during the years of 1985-1987(a-c) and comparing the simulated monthly runoff based on two precipitation datasets (APHRODITE and GT) and observed monthly runoff during 1984-1993(d). Note: TLR stands for the temperature lapse rate method; Combined represents the combined IDW and lapse rates method. MAE is mean absolute error; NSE is the Nash Sutcliffe efficiency. QoBs represents observed runoff; QAPH and $\mathrm{Q}_{\mathrm{GT}}$ denote simulated runoff based on APHRODITE and GT precipitation data, respectively 


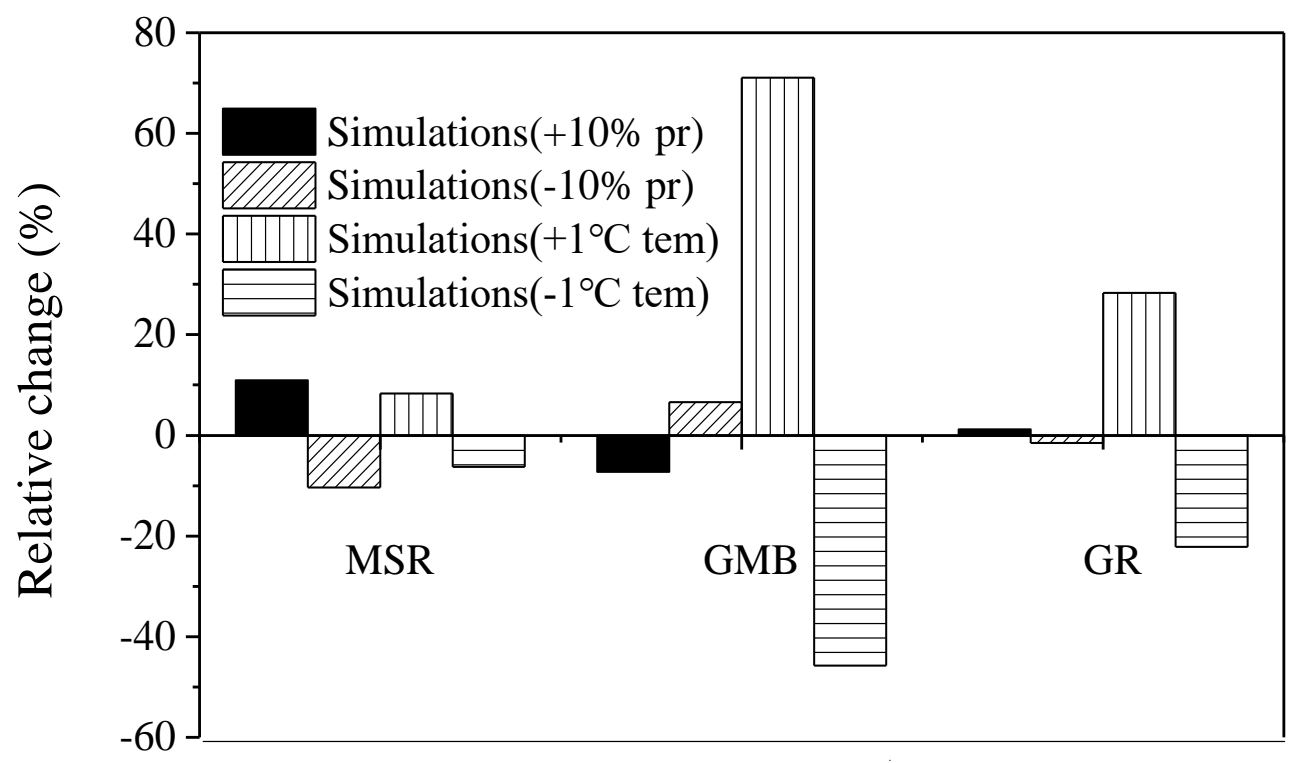

Figure 9 Influences of changing in precipitation and air temperature on modeling melt-season runoff (MSR), glacier mass balance (CMB) and glacier runoff (GR). Here "pr" and "tem" is precipitation and air temperature, respectively. 